\title{
Use of metformin is associated with lower incidence of cancer in patients with type 2 diabetes
}

\author{
Związek stosowania metforminy ze zmniejszoną zapadalnością na choroby \\ nowotworowe u pacjentów z cukrzycą typu 2
}

\author{
Alicja Muszyńska-Ogłaza', Grażyna Zarzycka-Lindner', Henryka Olejniczak', Mirosława Polaszewska- \\ -Muszyńska', Roman Junik ${ }^{2}$
}

${ }^{1}$ Centre for Diabetes and Endocrinology in Bydgoszcz, Bydgoszcz, Poland

${ }^{2}$ Clinic of Endocrinology and Diabetology, Nicolaus Copernicus University, Collegium Medicum, Bydgoszcz, Poland

\begin{abstract}
Introduction: The objective of the study was to assess the influence of metformin on the prevalence of cancer and risk factors for the development of cancer, in patients with type 2 diabetes.

Materials and methods: A total of 1063 patients, treated between October 2012 and March 2013 in the Diabetes and Endocrinology Centre in Bydgoszcz, were enrolled in the study. Only patients who were first diagnosed with diabetes and consecutively with cancer were included in the analysis. The final dataset compromised data from 1028 patients with type 2 diabetes, in whom retrospective analysis of the association between the occurrence of cancer and treatment with or without metformin was performed. Demographic data, medical history, physical assessment, diabetes history, diabetes complications, concomitant medication, and additional examination results were compared between two groups: those with cancer and those without cancer. Data were analysed using Student's t-test, Chi-square test with Yates' continuity correction, and multiple logistic regression.

Results: The most commonly observed cancer was breast cancer (24 patients; $22.5 \%$ ), followed by uterine cancer (15 patients; $13.6 \%)$. Of the 75 diabetic patients with a cancer diagnosis, $18.7 \%$ were treated with metformin; of the 953 patients without cancer, $38 \%$ received metformin. Analysis of probability of cancer occurrence using Kaplan-Meier curves showed that the probability of cancer development was higher in groups of patients who were not treated with metformin $(p=0.006)$.

Conclusions: Metformin treatment reduces the risk of cancer in type 2 diabetes patients. (Endokrynol Pol 2017; 68 (6): 652-658)
\end{abstract}

Key words: type 2 diabetes, metformin, cancer

\section{Streszczenie}

Wstęp: Metformina jest zalecana w profilaktyce raka u pacjentów z cukrzycą typu 2 (t2). Celem badania była ocena wpływu metforminy na częstość występowania raka i czynników ryzyka wystąpienia raka u pacjentów z cukrzycą typu 2.

Materiał i metody: W badaniu wzięło udział 1063 pacjentów leczonych od października 2012 do marca 2013 w Bydgoskim Centrum Diabetologii i Endokrynologii. Do analizy włączono pacjentów, u których najpierw rozpoznano cukrzycę, a następnie raka. Ostatecznie uzyskano dane od 1028 pacjentów z cukrzycą t2, na podstawie których przeprowadzono retrospektywną analizę związku między wystąpieniem nowotworu a stosowaniem metforminy. Grupy pacjentów z rakiem i bez raka porównano pod względem danych demograficznych, historii medycznej, wyników badania przedmiotowego, historii i powikłań cukrzycy, leków przyjmowanych z powodu chorób towarzyszących oraz wyników badań dodatkowych. Analizę statystyczną przeprowadzono za pomocą testu t Studenta, testu chi kwadrat z poprawką Yatesa na nieciągłość i wielokrotnej regresji logistycznej.

Wyniki: Najczęściej obserwowanym rodzajem raka był rak sutka $(\mathrm{N}=24 ; 22,5 \%)$, a następnie rak macicy $(\mathrm{N}=15 ; 13,6 \%)$. Spośród 75 pacjentów chorujących na cukrzycę i nowotwór, 18,7\% było leczonych metforminą, natomiast spośród 953 pacjentów bez nowotworu, metforminę przyjmowało $38 \%$. Analiza prawdopodobieństwa wystąpienia raka za pomocą krzywych Kaplana-Meiera wykazała, że prawdopodobieństwo raka jest większe u pacjentów, którzy nie przyjmowali metforminy $(\mathrm{p}=0,006)$.

Wnioski: Metformina zmniejsza ryzyko raka u pacjentów z cukrzycą t2. (Endokrynol Pol 2017; 68 (6): 652-658)

Słowa kluczowe: cukrzyca typu 2, metformina, rak

\section{Introduction}

Current epidemiological data suggest patients with diabetes have an increased risk of developing different types of cancer [1, 2]; in addition, there are reports of certain cancers developing more commonly in patients with type 2 diabetes [2]. Several types of cancer have been associated with obesity [2], as well as with type 2 diabetes; for example, breast cancer [2, 3, 4], endometrial cancer $[2,5,6]$, pancreatic cancer $[2,4]$, and colorectal cancer $[2,4,7]$. Insulin resistance and hyperinsulinemia may promote carcinogenesis either directly through the 
insulin receptor or indirectly by increasing the levels of insulin-like growth factors (IGF). Understanding the relationship between diabetes and cancer, and their associated comorbidities and complications, may have important implications for the prevention and management of these disorders $[1,8,9]$.

There are many means by which type 2 diabetes is currently treated. A drug commonly used as an initial and combined therapy is metformin [2], which reduces levels of circulating glucose and insulin in patients who suffer from hyperinsulinaemia caused by insulin resistance [2]. The primary mode of action of metformin is through reduced hepatic glucose output [2, 10]. Madiraju et al. showed that the mechanism of action included the following: delayed intestinal glucose absorption, enhanced release of glucagon-like peptide 1 , augmented lactate production by enterocytes, and activation of AMP-activated protein kinase in hepatocytes as a result of decreased energy charge, as well as inhibition of glucagon signalling, glycolytic enzymes, transcription of gluconeogenic enzymes, or mitochondrial complex I [11, 12].

Medications used for the treatment of hyperglycaemia may either increase or reduce the risk of developing cancer [2]. Metformin is widely used in patients with type 2 diabetes and has been shown to reduce the risk of cancer in those patients - both in small-scale studies [13] and in the multicentre randomised controlled UK Prospective Diabetes Study [14]. Not all agree on this association: a large, retrospective, population-based study using information from the healthcare databases in Ontario, Canada, failed to confirm the association between metformin treatment and reduced risk of prostate cancer in elderly men with diabetes [15]. Importantly, the study acknowledges the differences in study population characteristics to other work [15], and states that the populations in which the metformin effect on cancer risk was not observed were older, comorbid, and had worse grade distribution than most prostate cancer cohorts (contemporary cancer cohorts) [15]. It is possible that in a younger cohort metformin used for the treatment of type 2 diabetes may have a positive effect on cancer risk [15].

The aim of the study was to assess the influence of treatment with metformin on the prevalence of cancer in patients with type 2 diabetes, and to assess risk factors, by comparing clinical characteristics of patients with cancer and those without cancer.

\section{Materials and methods}

\section{Study population}

A total of 1063 patients treated in the Diabetes and Endocrinology Centre in Bydgoszcz, who were involved in the national health program "Comprehensive Specialist Outpatient Care" (in Polish: Kompleksowa Ambulatoryjna
Opieka Specjalistyczna - KAOS), were enrolled in the retrospective study. The program is provided by the Polish national health care system to patients with chronic diseases, including those with type 1 diabetes, type 2 diabetes requiring insulin, and gestational diabetes. The aim of this program is to standardise specialist care of patients with chronic diseases and to secure the best patient management. In the case of patients with diabetes, the program covers a wide spectrum of specialist consultants.

Only patients who were first diagnosed with diabetes and consecutively with cancer were included in the analysis. As such, 20 patients for whom the diagnosis of cancer was reported before the onset of diabetes were excluded, as were 15 patients without a date of diagnosis of cancer. Patients for whom multiple cancers were reported were included in the study only once. The final dataset for analysis compromised data from 1028 patients with type 2 diabetes, for whom the association between cancer occurrence and treatment (with or without metformin) was analysed. The patient population was divided into two groups: with cancer and without cancer.

\section{Patient data}

The following data were collected:

- Demographics and medical history: age, sex, duration of diabetes, and comorbidities (e.g. hypertension, infarct, stroke, atrial fibrillation, atherosclerosis, aneurysm)

- Physical examinations: body mass index (BMI), systolic and diastolic blood pressure

- Diabetes: year of diagnosis, complications (e.g. retinopathy, diabetic foot, atherosclerosis, polyneuropathy), and antidiabetic treatment

- Concomitant medications: Acidum acetylsalicylicum, beta-blockers, alpha-blockers, calcium channel blockers, ACE-I, ARB, thiazides, statins, fibrates

- Additional examinations: level of glycated haemoglobin $\left(\mathrm{HbA}_{1 \mathrm{c}}\right)$, creatinine concentration, glomerular filtration rate, protein concentration in urine, aminotransferases activity, abdomen ultrasonography, and echocardiography.

Data about types of cancers were collected and coded according to the International Statistical Classification of Diseases and Related Health Problems $10^{\text {th }}$ Revision (ICD-10) [16].

\section{Study timeframe}

All study visits took place between October 2012 and March 2013.

\section{Ethics}

The study was conducted after obtaining permission from the Ethics Committee, in accordance with Polish 
Table I. Characteristics of the study population stratified by gender

Tabela I. Charakterystyka badanej grupy w podziale na płeć

\begin{tabular}{lllll}
\hline & Women $(\mathbf{n}=\mathbf{5 2 3})$ & \multicolumn{2}{l}{ Men (n= 505) } \\
\hline & Mean & SD & Mean & SD \\
\hline $\begin{array}{l}\text { Ageat srudy visit } \\
\text { (years) }\end{array}$ & 69.3 & 8.93 & 66.4 & 8.50 \\
\hline $\begin{array}{l}\text { Ageat diagnosis of } \\
\text { diabetes (years) }\end{array}$ & 51.7 & 9.46 & 50.5 & 9.07 \\
\hline $\begin{array}{l}\text { Diabetes duration } \\
\text { (years) }\end{array}$ & 17.6 & 7.52 & 16.0 & 7.44 \\
\hline Height $(\mathrm{cm})$ & 158.8 & 6.09 & 172.3 & 6.44 \\
\hline Weight $(\mathrm{kg})$ & 82.2 & 13.75 & 91.4 & 15.37 \\
\hline $\mathrm{BMI}\left(\mathrm{kg} / \mathrm{m}^{2}\right)$ & 32.6 & 5.13 & 30.8 & 4.87 \\
\hline $\mathrm{HbA} \mathrm{I}_{\mathrm{lc}}(\%)$ & 8.1 & 1.23 & 8.0 & 1.38 \\
\hline
\end{tabular}

Law and appropriate EU regulations on non-interventional studies.

\section{Statistics}

The statistical data are reported as the number of patients (n), mean (SD), median (IQR), or percentage. Comparisons of the data between patients with and without cancer were performed using a Student's t-test (for numeric variables) and Chi-square test with Yates' continuity correction (for categorical variables). Multiple logistic regression was used to examine the relationship between treatment (with or without metformin) and cancer incidence, age at study visit, and metformin use. P-values less than or equal to 0.05 were considered statistically significant.

\section{Results}

\section{Characteristics of study population}

The mean age of 1028 analysed patients was 67.9 years (SD 8.84 years). Women constituted $51 \%$ and men $49 \%$ of the study population. The differences between the men and women in the study population are shown in Table I.

Overall, the mean duration of diabetes was 16.8 years (SD 7.54 years); the average patient weight was $86.7 \mathrm{~kg}$ (SD $15.2 \mathrm{~kg}$ ), and the mean body mass index (BMI) was $31.7 \mathrm{~kg} / \mathrm{m}^{2}$ (SD $\left.5.08 \mathrm{~kg} / \mathrm{m}^{2}\right)$. Of all enrolled patients, $46 \%$ had retinopathy, $20.8 \%$ polyneuropathy, $9.5 \%$ diabetic foot, $7.7 \%$ nephropathy, and $2.6 \%$ carotid atherosclerosis. In terms of treatments, $77.8 \%$ were treated with statins, $69.9 \%$ with beta-blockers, $66 \%$ with acetylsalicylic acid, $42 \%$ with thiazides, $38.1 \%$ with Ca-blockers, $11 \%$ with fibrates, and $3 \%$ with alpha-blockers. The mean $\mathrm{HbA}_{1 \mathrm{c}}$ in the total study population was $8.1 \%$ (SD 1.31\%). The mean glomerular filtration rate was $68.2 \mathrm{~mL} / \mathrm{min}$.
Table II. Types of cancer observed in the study population, by ICD-10 codes

Tabela II. Typy nowotworów zaobserwowane w badanej grupie, sklasyfikowane wedtug ICD-10

\begin{tabular}{|c|c|c|c|c|}
\hline $\begin{array}{l}\text { General } \\
\text { code }\end{array}$ & $\begin{array}{l}\text { ICD- } \\
10\end{array}$ & ICD Group & Cancer group & $\begin{array}{l}\text { Number } \\
\text { of } \\
\text { reported } \\
\text { cancers }\end{array}$ \\
\hline C00-C14 & C11 & $\begin{array}{l}\text { Malignant } \\
\text { neoplasms of lip, } \\
\text { oral cavity and } \\
\text { pharynx }\end{array}$ & $\begin{array}{l}\text { Nasopharyngeal } \\
\text { cancer }\end{array}$ & 1 \\
\hline \multirow[t]{5}{*}{ C15-C26 } & C18 & & Ca colon & 11 \\
\hline & C19 & \multirow{4}{*}{$\begin{array}{l}\text { Malignant } \\
\text { neoplasms of } \\
\text { digestive organs }\end{array}$} & Ca sigmae & 4 \\
\hline & $\mathrm{C} 20$ & & Ca recti & 7 \\
\hline & $\mathrm{C} 22$ & & Liver cancer & 1 \\
\hline & $\mathrm{C} 25$ & & Ca pancreas & 1 \\
\hline \multirow[t]{3}{*}{ С30-С39 } & C32 & \multirow{3}{*}{$\begin{array}{l}\text { Malignant } \\
\text { neoplasms of } \\
\text { respiratory and } \\
\text { intrathoracic organs }\end{array}$} & Larynx cancer & 2 \\
\hline & $\mathrm{C} 34$ & & Lung cancer & 6 \\
\hline & & & Ca bronchi & 1 \\
\hline \multirow[t]{2}{*}{ C44 } & \multirow[t]{2}{*}{ C44 } & \multirow{2}{*}{$\begin{array}{l}\text { Other malignant } \\
\text { neoplasms of skin }\end{array}$} & Ca skin & 3 \\
\hline & & & Basalioma & 3 \\
\hline C45-C49 & $\mathrm{C} 49$ & $\begin{array}{l}\text { Malignant } \\
\text { neoplasms of } \\
\text { mesothelial and soft } \\
\text { tissue }\end{array}$ & $\begin{array}{l}\text { Retroperitoneal } \\
\text { Liposarcoma }\end{array}$ & 1 \\
\hline \multirow[t]{2}{*}{$\mathrm{C} 50$} & \multirow[t]{2}{*}{$\mathrm{C} 50$} & \multirow{2}{*}{$\begin{array}{l}\text { Malignant } \\
\text { neoplasms of breast } \\
\text { tissue }\end{array}$} & Breast cancer & 23 \\
\hline & & & Breast tumor & 1 \\
\hline \multirow[t]{5}{*}{ C51-C58 } & $\mathrm{C53}$ & \multirow{5}{*}{$\begin{array}{l}\text { Malignant } \\
\text { neoplasms of female } \\
\text { genitalia }\end{array}$} & Ca of cervix uteri & 1 \\
\hline & $\mathrm{C} 54$ & & Ca of corpus & 7 \\
\hline & C55 & & & \\
\hline & $\mathrm{C} 56$ & & $\begin{array}{l}\text { Ca uteri, part } \\
\text { unspecified }\end{array}$ & 7 \\
\hline & & & Caovary & 2 \\
\hline \multirow[t]{3}{*}{ C60-C63 } & $\mathrm{C60}$ & \multirow{3}{*}{$\begin{array}{l}\text { Malignant } \\
\text { neoplasms of male } \\
\text { genitalia }\end{array}$} & Penis cancer & 1 \\
\hline & C61 & & Ca prostate & 10 \\
\hline & C62 & & Ca testis & 1 \\
\hline \multirow[t]{2}{*}{ C64-C68 } & C64 & \multirow{2}{*}{$\begin{array}{l}\text { Malignant } \\
\text { neoplasms of the } \\
\text { urinary tract }\end{array}$} & \multirow{2}{*}{$\begin{array}{l}\text { Ca kidney ca } \\
\text { bladder }\end{array}$} & 5 \\
\hline & C67 & & & 5 \\
\hline C71 & C71 & $\begin{array}{l}\text { Malignant neoplasms } \\
\text { of the brain }\end{array}$ & Brain cancer & 1 \\
\hline C73-C75 & $\mathrm{C} 73$ & $\begin{array}{l}\text { Malignant } \\
\text { neoplasms of } \\
\text { thyroid and other } \\
\text { endocrine glands }\end{array}$ & Ca thyroid & 1 \\
\hline \multirow[t]{5}{*}{ C81-С96 } & $\mathrm{C} 81$ & \multirow{4}{*}{$\begin{array}{l}\text { Malignant } \\
\text { neoplasms, stated } \\
\text { or presumed } \\
\text { to be primary, } \\
\text { of lumphoid, } \\
\text { hematopoietic and } \\
\text { related tissues }\end{array}$} & Hodgkin & 1 \\
\hline & C86 & & lymphoma & \\
\hline & $\mathrm{C} 91$ & & Lymphoma & 1 \\
\hline & & & Leukemia & 6 \\
\hline & $\mathrm{D} 46$ & & $\begin{array}{l}\text { Myelodysplastic } \\
\text { syndrome }\end{array}$ & 1 \\
\hline
\end{tabular}


Table III. Comparison of clinical data of patients with and without cancer

Tabela III. Porównanie danych klinicznych pacjentów $z$ nowotworem $i$ bez nowotworu

\begin{tabular}{|c|c|c|c|}
\hline & $\begin{array}{l}\text { Patients with } \\
\text { cancer }\end{array}$ & $\begin{array}{l}\text { Patients } \\
\text { without }\end{array}$ & \\
\hline & $(n=75)$ & $\begin{array}{l}\text { cancer } \\
(\mathrm{n}=953)\end{array}$ & \\
\hline & Mean (SD) & Mean (SD) & $\mathbf{p}$ \\
\hline Females (\%) & 56 & 51 & 0.422 \\
\hline Metformin (\%) & 19 & 38 & 0.001 \\
\hline $\begin{array}{l}\text { Age at study visit } \\
\text { (years) }\end{array}$ & $71.1(7.47)$ & $67.7(8.89)$ & 0.001 \\
\hline $\begin{array}{l}\text { Age at diabetes } \\
\text { diagnosis (years) }\end{array}$ & $51.9(8.89)$ & $51.0(9.33)$ & 0.433 \\
\hline $\begin{array}{l}\text { Age at cancer } \\
\text { (years) }\end{array}$ & $64.8(7.78)$ & & \\
\hline $\begin{array}{l}\text { Diabetes duration } \\
\text { (years) }\end{array}$ & $19.3(7.23)$ & $16.6(7.54)$ & 0.003 \\
\hline $\begin{array}{l}\text { Time from diagnosis } \\
\text { of cancer (years ) }\end{array}$ & $12.9(6.92)$ & & \\
\hline $\begin{array}{l}\text { Diastolic blood } \\
\text { pressure }(\mathrm{mmHg})\end{array}$ & $77.4(13.05)$ & $79.0(11.26)$ & 0.183 \\
\hline $\begin{array}{l}\text { Systolic blood } \\
\text { pressure } \\
(\mathrm{mmHg})\end{array}$ & $149.1(21.3)$ & $146.9(18.77)$ & 0.329 \\
\hline $\begin{array}{l}\text { Body Mass Index } \\
\left(\mathrm{kg} / \mathrm{m}^{2}\right)\end{array}$ & $31.7(5.05)$ & $31.7(5.08)$ & 0.747 \\
\hline $\mathrm{HbA}_{\mathrm{Ic}}(\%)$ & $7.9(1.31)$ & $8.1(1.31)$ & 0.597 \\
\hline
\end{tabular}

\section{Cancer population}

Of the total patient population, $\sim 10 \%$ (110 patients) were reported to have cancer, with 115 cases of cancer reported. In one patient three cancer occurrences were reported, and in three patients two cancer occurrences were reported. The most commonly observed cancer was breast cancer ( 24 patients; $22.5 \%$ ), followed by uterine cancer (15 patients; $13.6 \%)$. Eleven patients $(10 \%)$ were diagnosed with colon cancer, and another $10 \%$ with prostate cancer. The cancer types observed in our study population are summarised in Table II.

\section{Comparison of patients with and without cancer}

The time from onset of diabetes to the diagnosis of cancer in patients treated with metformin $(\mathrm{n}=14)$ was 9.6 years (SD 5.67 years); the time from onset of diabetes to the first study visit in patients without cancer treated with metformin $(\mathrm{n}=362)$ was 15.6 years $(\mathrm{SD}$ 6.55 years). The corresponding data for patients who did not receive metformin was 13.7 years (SD 6.99 years) for patients who developed cancer $(\mathrm{n}=61)$, and 17.3 years (SD 8.02 years) for patients who did not develop
Table IV. Comparison of diabetes complications in patients with and without cancer

Tabela IV. Porównanie powikłań cukrzycy z nowotworem i bez nowotworu

\begin{tabular}{llllll}
\hline & \multicolumn{2}{l}{$\begin{array}{l}\text { Patients } \\
\text { with cancer }\end{array}$} & $\begin{array}{l}\text { Patients } \\
\text { without cancer }\end{array}$ \\
\hline & (n= 75) & \multicolumn{2}{l}{ (n = 953) } & \\
\cline { 2 - 6 } & N & $\%$ & & $\%$ & p \\
\hline Complications & & & & & 0.869 \\
\hline No & 27 & 36 & 359 & 37.7 & \\
\hline Yes & 48 & 64 & 594 & 62.3 & \\
\hline Retinopathy & & & & & 0.651 \\
\hline No & 38 & 50.7 & 515 & 54 & \\
\hline Yes & 37 & 49.3 & 438 & 46 & \\
\hline Diabetic foot & & & & & 0.797 \\
\hline No & 69 & 92 & 861 & 90.3 & \\
\hline Yes & 9 & 8 & 92 & 9.7 & \\
\hline Carotid atherosclerosis & & & & \\
\hline No & 74 & 98.7 & 927 & 97.3 & \\
\hline Yes & 1 & 1.3 & 26 & 2.7 & \\
\hline Polyneuropathy & & & & & 0.357 \\
\hline No & 63 & 84 & 751 & 78.8 & \\
\hline Yes & 12 & 16 & 202 & 21.2 & \\
\hline Microalbuminuria & & & & & \\
\hline 30 mg/day & & & & & \\
\hline No & 71 & 94.7 & 878 & 92.1 & \\
\hline Yes & 5 & 5.7 & 75 & 7.9 & \\
\hline & & & & \\
\hline & & & & & \\
\hline
\end{tabular}

cancer $(n=591)$. Differences between patients with and without cancer were found when comparing diabetes duration and age at last follow-up $(\mathrm{p}<0.05)$. When comparing the groups in terms of age at diabetes onset, diastolic and systolic blood pressure, BMI, or $\mathrm{HbA1c}$, no differences were observed (Table III). When comparing complications of diabetes, no differences were observed (Table IV).

\section{Analysis of metformin treatment and risk of cancer}

Of the 75 diabetic patients with a cancer diagnosis, $18.7 \%$ were treated with metformin; whereas, $38 \%$ of the 953 patients without cancer received metformin. An analysis of metformin treatment and cancer development is shown in Table V. Additionally, the negative association between age at study visit and use of metformin was identified (estimate: $-0.043 ; \mathrm{p}<0.0001$ ).

\section{Risk of cancer}

Using only patients with complete follow-up information and a positive follow-up time, multiple logistic 
Table V. Comparison of patients with and without cancer, stratified by treatment

Tabela V. Porównanie pacjentów z nowotworem $i$ bez nowotworu w zależności od rodzaju terapii

\begin{tabular}{|c|c|c|c|c|c|c|}
\hline Metformin & & Cancer & $\mathbf{N}$ & Mean & SD & $\mathbf{p}$ \\
\hline \multirow{6}{*}{ No } & \multirow{2}{*}{$\begin{array}{l}\text { Age at } \\
\text { study visit } \\
\text { (years) }\end{array}$} & No & 591 & 68.81 & 9.401 & \\
\hline & & Yes & 61 & 72.02 & 7.152 & 0.002 \\
\hline & \multirow{2}{*}{$\begin{array}{l}\text { Age at } \\
\text { diabetes } \\
\text { diagnosis } \\
\text { (years) }\end{array}$} & No & 591 & 51.52 & 9.726 & \\
\hline & & Yes & 61 & 52.23 & 8.543 & 0.590 \\
\hline & \multirow{2}{*}{$\begin{array}{l}\text { Diabetes } \\
\text { duration } \\
\text { (years) }\end{array}$} & No & 591 & 17.28 & 8.021 & \\
\hline & & Yes & 61 & 19.79 & 7.492 & 0.020 \\
\hline \multirow{6}{*}{ Yes } & \multirow{2}{*}{$\begin{array}{l}\text { Age at last } \\
\text { follow-up } \\
\text { (years) }\end{array}$} & No & 362 & 65.79 & 7.644 & \\
\hline & & Yes & 14 & 67.21 & 7.837 & 0.500 \\
\hline & \multirow{2}{*}{$\begin{array}{l}\text { Age at } \\
\text { diabetes } \\
\text { diagnosis } \\
\text { (years) }\end{array}$} & No & 362 & 50.19 & 8.589 & \\
\hline & & Yes & 14 & 50.29 & $10 / 499$ & 0.970 \\
\hline & \multirow{2}{*}{$\begin{array}{l}\text { Diabetes } \\
\text { duration } \\
\text { (years) }\end{array}$} & No & 362 & 15.60 & 6.553 & \\
\hline & & Yes & 14 & 16.93 & 5.609 & 0.460 \\
\hline
\end{tabular}

regression showed metformin treatment had a significant positive effect on cancer incidence $(p=0.006)$. In addition, this analysis indicated that the longer the duration of diabetes, the greater the risk of cancer $(\mathrm{p}=$ $0.032)$ and that the use of acetylsalicylic acid ( $p=0.002)$ (Table VI). The age of diabetes onset, gender, and BMI did not prove to be predictors of cancer, nor did $\mathrm{HbA}_{1 \mathrm{c}}$ level, acetylsalicylic acid dose, non-proliferative retinopathy, proliferative retinopathy, diabetic foot, carotid atherosclerosis, polyneuropathy and nephropathy, or anticoagulant therapy (Table VI). Analysis using Kaplan-Meier curves showed that the probability of developing cancer was higher in patients who were not treated with metformin, compared to those who were $(p=0.006$; Fig. 1).

\section{Discussion}

In the current study, we observed metformin to have a protective effect in patients with type 2 diabetes, specifically by preventing the development of cancer. The study was performed in patients who were under strict professional control because they belonged to the Comprehensive Outpatient Specialist Care program. Our findings are supported by a comparison of metformin-treated and untreated patients, as well as by multiple logistic regression. Our Kaplan-Meier curves also showed that the risk of developing cancer was higher in patients who
Table VI. Multiple logistic regression of patients with complete information

Tabela VI. Wielokrotna regresja logistyczna u pacjentów $z$ kompletnymi danymi

\begin{tabular}{lrrrr}
\hline & Estimate & $\begin{array}{c}\text { Standard Z value } \\
\text { error }\end{array}$ & P value \\
\hline (Intercept) & -4.082 & 1.667 & -2.448 & 0.014 \\
\hline Diabetes duration & $\mathbf{0 . 0 4 4}$ & $\mathbf{0 . 0 2 1}$ & $\mathbf{2 . 0 9 9}$ & $\mathbf{0 . 0 3 6}$ \\
\hline Age at diabetes onset & 0.021 & 0.017 & 1.218 & 0.223 \\
\hline BMI & 0.031 & 0.029 & 1.086 & 0.277 \\
\hline Gender (woman) & 0.047 & 0.276 & 0.169 & 0.865 \\
\hline Metformin & $-\mathbf{0 . 9 4 0}$ & $\mathbf{0 . 3 4 1}$ & $\mathbf{- 2 . 7 5 8}$ & $\mathbf{0 . 0 0 6}$ \\
\hline Complications & -0.064 & 0.285 & -0.226 & 0.821 \\
\hline HbAIC & -0.038 & 0.108 & -0.352 & 0.725 \\
\hline Beta blocker & 0.225 & 0.308 & 0.730 & 0.466 \\
\hline Thiazides diuretics & -0.296 & 0.298 & -0.994 & 0.320 \\
\hline Loop diuretics & 0.254 & 0.372 & 0.683 & 0.494 \\
\hline Potassium-sparing & -0.806 & 0.631 & -1.277 & 0.202 \\
diuretics & & & & \\
\hline Acetylsalicylic acid & $-\mathbf{0 . 8 5 9}$ & $\mathbf{0 . 2 7 7}$ & $-\mathbf{3 . 1 0 4}$ & $\mathbf{0 . 0 0 2}$ \\
\hline Stalin & -0.234 & 0.314 & -0.748 & 0.455 \\
\hline Fibrate & -0.735 & 0.618 & -1.189 & 0.235 \\
\hline Alfa blocker & -15.374 & 730.262 & -0.021 & 0.983 \\
\hline Ca blocker & 0.101 & 0.286 & -0.353 & 0.724 \\
\hline Anticoagulants & 0.260 & 0.433 & 0.602 & 0.547 \\
\hline & & & & \\
\hline & & & \\
\hline
\end{tabular}

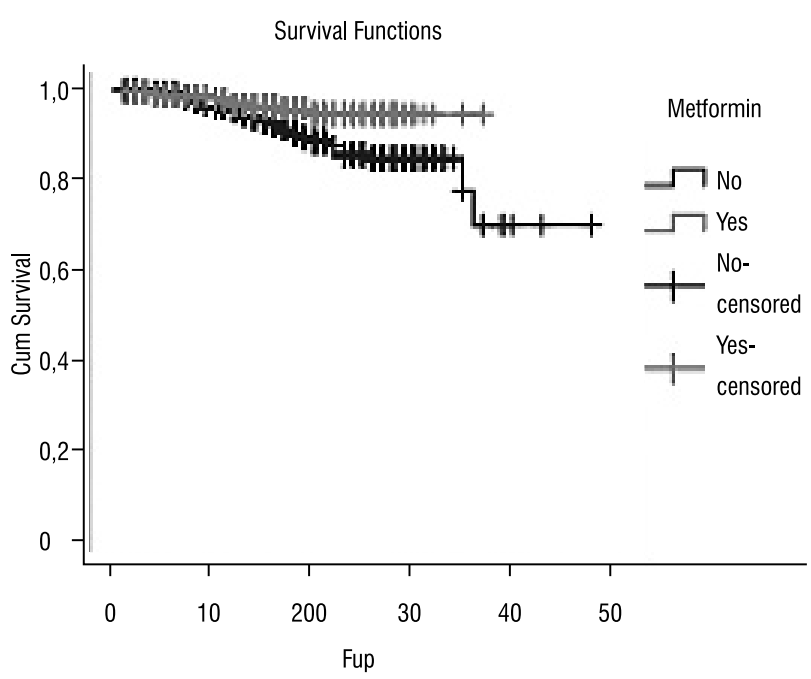

Figure 1. Analysis of the probability of cancer development using Kaplan-Meier curves. Log Rank (Mantel-Cox) $(p=0.006)$

Rycina 1. Prawdopodobieństwo wystapienia nowotworu przedstawione za pomoca krzywej Kaplana-Meiera. Log Rank (Mantel-Cox) $(p=0,006)$

were not treated with metformin. This observation is in line with the currently understood mechanism of action of metformin. 
Metformin is likely to inhibit cell proliferation and reduce colony formation, as shown in in vitro studies of cancer cell lines [2,17-19]. It induces muscles to take up glucose from the blood through targeting of the AMP-activated protein kinase (AMPK). The mechanism is also known to be dependent on the activation of the protein kinase LKB1 - a tumour suppressor [13]. It is probable that this correlation is beneficial in the primary and secondary prevention of certain types of cancers [13]. It is most probable that the influence of metformin on LKB1 or AMPK is secondary to its effect on mitochondria, which are the primary target of the drug [20]. The intensive glucose control observed following metformin treatment appeared to reduce the risk of diabetes-related health complications (including death) when compared to insulin and sulfonylureas [20]. Metformin may show a prevention role of cancer [21]. Metformin-induced activation of AMPK in tumour cells is suggested to lead to inhibition of cell growth, at least in part by inhibiting protein synthesis [2]. Another mode of action of metformin might be through an AMPK-mediated regulation of fatty acid synthesis. Prostate, breast, and colon cancers cells constitutively over-express fatty acid synthase, which is a key enzyme for de novo fatty acid biosynthesis, and has been associated with the malignant phenotype. Another potential mechanism is based on the positive impact of metformin on chronic inflammation. Metformin not only inhibits the proliferation of cancer cells, it also promotes cell death of these same cells by activating apoptotic pathways. It has also been suggested that metformin can inhibit the growth of cancer cells by decreasing their energy status and forcing a metabolic conversion that cancer cells are unable to execute [21].

Results of other observational human studies also indicate that therapy with metformin is associated with reduced risk of cancer [2, 13, 22-24] and cancer mortality $[2,25]$. Observational data suggest metformin might improve cancer prognosis as well [2].

Type 2 diabetes is associated with increased risk of cancer affecting the breast, colon, prostate, kidney, and pancreas $[2,21]$. The most common type of cancer observed in patients in our study population was breast cancer, which is similar to the observations of Giovanucci et al. [2], Michels et al. [3], and Coughlin et al. [4]. Other common cancers included uterine cancer, colon cancer, and prostate cancer. A number of studies have discussed the mechanisms underlying the relationship between diabetes and cancer; however, a metabolic or biochemical reliance is thought to be key. The association between the two diseases appears to be mediated through the metabolic system [1]. Both diseases, which are likely to be biologically linked through an as-yet-unknown mechanism, share the range of potential risk factors: both modifiable and non-modifiable [2]. Non-modifiable risk factors are: age, gender, and ethnicity; whereas, modifiable risk factors are: weight, obesity, weight change, diet, physical activity, smoking status, and alcohol consumption [2]. In the current study, we did not observe any relationship between BMI and risk of cancer development. It has been observed that both the occurrence of cancer and diabetes increase with age and gender: men have a slightly higher age-adjusted risk of diabetes than women [2]. In the current study, gender did not influence the risk of cancer development.

The incidence of tumours in the current study was almost twice that recently reported for the general Polish population of patients with type 2 diabetes (5.9\%) [26]. This result can be explained by the nature of the patients included in the Comprehensive Outpatient Specialist Care program when compared with the general population; specifically, patients included in this program are at a more advanced disease stage but, at the same time, they are subjected to more thorough care with better screening of other comorbid diseases. In addition, the observed incidence of the individual tumours is a little different, and may be explained by differences between study populations (for example, diabetes duration). Like the authors of other studies, we did not observe a correlation between the incidence of cancer and the degree of glycaemic control (as measured by glycated haemoglobin levels), weight, or duration of diabetes. Perhaps such a relationship would be able to be observed for individual types of cancer, but the study would require a larger population.

The results of our study should be interpreted with caution, in light of the retrospective nature of the study. We did not have the exact date of metformin implementation, and assumed that metformin had been administered very early in the course of diabetes; that is, that the duration of diabetes was equal to the duration of treatment with metformin. Moreover, we did not have information about other risk factors for cancer development, such as family history or lifestyle parameters. Another limitation of our study was the fact that our population differed from the general population with type 2 diabetes. First of all, the patients covered by the Comprehensive Outpatient Specialist Care program suffered from more advanced type 2 diabetes, and appeared to have more problems with controlling the disease, as indicated by an increased $\mathrm{HbA}_{1 \mathrm{c}}$ value. The mean $\mathrm{HbA}_{1 \mathrm{c}}$ in our study was slightly higher than in the patient population reported by Sieradzki et al. (mean $\mathrm{HbA}_{1 \mathrm{c}}-7.7 \%$ ), who nevertheless postulated the need for earlier and more intensive treatment [27]. Therefore, we would like to reiterate that our findings are specific to the population of patients with more 
severe and poorer controlled type 2 diabetes compared to the overall population. Finally, we should underline that the negative association between metformin use and age could at least partly contribute to the observed association between metformin use and the likelihood of cancer. The association between metformin use and age was weak, and that is why we would consider it as a minor confounder. All of these facts need to be taken into account when interpreting the results of our study.

\section{Conclusions}

To conclude, as suggested by many observational studies, therapy with metformin reduces the risk of cancer. In our trial, the protective effect of metformin was confirmed. These results are of high clinical significance becuase metformin is widely used, generally well tolerated, and commonly accepted. Long-term observational trials in larger group of patients should be performed, and they will be crucial in directing future research.

\section{Acknowledgements}

The authors thank Proper Medical Writing, Warsaw, Poland for the language assistance and medical writing provided in the preparation of this paper.

\section{Author Disclosures}

The authors declare no conflict of interests.

\section{Role of the funding source}

Medical writing, statistical analysis, and editorial assistance was provided by Proper Medical Writing, Warsaw, Poland and funded by a grant from Novo Nordisk. The authors take full responsibility for the content and conclusions stated in this manuscript. Novo Nordisk neither influenced the content of this publication nor was it involved in the study design, data collection, analysis, or interpretation.

\section{Founding source}

Medical writing, statistical analysis, and editorial assistance was funded by a grant from Novo Nordisk.

\section{References}

1. Bowker SL, Pohar SL, Johnson JA. A cross-sectional study of healthrelated quality of life deficits in individuals with comorbid diabetes and cancer. Health Qual Life Outcomes. 2006; 4: 17, doi: 10.1186/1477-75254-17, indexed in Pubmed: 16553957.

2. Giovannucci E, Harlan DM, Archer MC, et al. Diabetes and cancer: a consensus report. CA Cancer J Clin. 2010; 60(4): 207-221, doi: 10.3322/ caac.20078, indexed in Pubmed: 20554718.

3. Michels KB, Solomon CG, Hu FB, et al. Nurses' Health Study. Type 2 diabetes and subsequent incidence of breast cancer in the Nurses' Health Study. Diabetes Care. 2003; 26(6): 1752-1758, doi: 10.2337/diacare.26.6.1752, indexed in Pubmed: 12766105

4. Coughlin SS, Calle EE, Teras LR, et al. Diabetes mellitus as a predictor of cancer mortality in a large cohort of US adults. Am J Epidemiol. 2004; 159(12): 1160-1167, doi: 10.1093/aje/kwh161, indexed in Pubmed: 15191933.
5. Weiderpass E, Persson I, Adami HO, et al. Body size in different periods of life, diabetes mellitus, hypertension, and risk of postmenopausal endometrial cancer (Sweden). Cancer Causes Control. 2000; 11(2): 185-192, indexed in Pubmed: 10710204.

6. Maatela J, Aromaa A, Salmi T, et al. The risk of endometrial cancer in diabetic and hypertensive patients: a nationwide record-linkage study in Finland. Ann Chir Gynaecol Suppl. 1994; 208: 20-24, indexed in Pubmed: 8092764

7. Hu FB, Manson JE, Liu S, et al. Prospective study of adult onset diabetes mellitus (type 2) and risk of colorectal cancer in women. J Natl Cancer Inst. 1999; 91(6): 542-547, doi: 10.1093/jnci/91.6.542, indexed in Pubmed: 10088625.

8. Rosenfeld RG. Insulin-like growth factors and the basis of growth N Engl J Med. 2003; 349(23): 2184-2186, doi: 10.1056/NEJMp038156, indexed in Pubmed: 14657423.

9. Kim YI. Diet, lifestyle, and colorectal cancer: is hyperinsulinemia the missing link? Nutr Rev. 1998; 56(9): 275-279, doi: 10.1111/j.1753-4887.1998. tb01765.x, indexed in Pubmed: 9763878.

10. Shaw RJ, Lamia KA, Vasquez D, et al. The kinase LKB1 mediates glucose homeostasis in liver and therapeutic effects of metformin. Science. 2005; 310(5754): 1642-1646, doi: 10.1126/science.1120781, indexed in Pubmed: 16308421

11. Ferrannini E. The Target of Metformin in Type 2 Diabetes. N Engl J Med. 2014; 371(16): 1547-1548, doi: 10.1056/nejmcibr1409796.

12. Madiraju AK, Erion DM, Rahimi Y, et al. Metformin suppresses gluconeogenesis by inhibiting mitochondrial glycerophosphate dehydrogenase. Nature. 2014; 510(7506): 542-546, doi: 10.1038/nature13270, indexed in Pubmed: 24847880

13. Evans JMM, Donnelly LA, Emslie-Smith AM, et al. Metformin and reduced risk of cancer in diabetic patients. BMJ. 2005; 330(7503): 1304-1305, doi: 10.1136/bmj.38415.708634.F7, indexed in Pubmed: 15849206.

14. UK Prospective Diabetes Study (UKPDS) Group. Effect of intensive blood-glucose control with metformin on complications in overweight patients with type 2 diabetes (UKPDS 34). Lancet. 1998; 352(9131): 854-865, doi: 10.1016/s0140-6736(98)07037-8, indexed in Pubmed: 9742977.

15. Margel D, Urbach D, Lipscombe LL, et al. Association between metformin use and risk of prostate cancer and its grade. J Natl Cancer Inst. 2013; 105(15): 1123-1131, doi: 10.1093/jnci/djt170, indexed in Pubmed: 23853056.

16. International Statistical Classification of Diseases and Related Health Problems 10th Revision. http://apps.who.int/classifications/icd10/ browse/2015/en (2015)

17. Zakikhani M, Dowling R, Fantus IG, et al. Metformin is an AMP kinasedependent growth inhibitor for breast cancer cells. Cancer Res. 2006; 66(21): 10269-10273, doi: 10.1158/0008-5472.CAN-06-1500, indexed in Pubmed: 17062558 .

18. Alimova IN, Liu B, Fan Z, et al. Metformin inhibits breast cancer cell growth, colony formation and induces cell cycle arrest in vitro. Cell Cycle. 2009; 8(6): 909-915, doi: 10.4161/cc.8.6.7933, indexed in Pubmed: 19221498.

19. Liu B, Fan Z, Edgerton SM, et al. Metformin induces unique biological and molecular responses in triple negative breast cancer cells. Cell Cycle. 2009; 8(13): 2031-2040, doi: 10.4161/cc.8.13.8814, indexed in Pubmed: 19440038

20. Currie CI, Poole CD, Gale EAM. The influence of glucose-lowering therapies on cancer risk in type 2 diabetes. Diabetologia. 2009; 52(9): 1766-1777, doi: 10.1007/s00125-009-1440-6, indexed in Pubmed: 19572116.

21. Viollet B, Guigas B, Sanz Garcia N, et al. Cellular and molecular mechanisms of metformin: an overview. Clin Sci (Lond). 2012; 122(6): 253-270, doi: 10.1042/CS20110386, indexed in Pubmed: 22117616.

22. Bowker SL, Majumdar SR, Veugelers P, et al. Increased cancer-related mortality for patients with type 2 diabetes who use sulfonylureas or insulin. Diabetes Care. 2006; 29(2): 254-258, doi: 10.2337/diacare.29.02.06. dc05-1558, indexed in Pubmed: 16443869.

23. Monami M, Lamanna C, Balzi D, et al. Sulphonylureas and cancer: a case-control study. Acta Diabetol. 2009; 46(4): 279-284, doi: 10.1007/ s00592-008-0083-2, indexed in Pubmed: 19082520.

24. Wright JL, Stanford JL. Metformin use and prostate cancer in Caucasian men: results from a population-based case-control study. Cancer Causes Control. 2009; 20(9): 1617-1622, doi: 10.1007/s10552-009-9407-y, indexed in Pubmed: 19653109.

25. Landman GWD, Kleefstra N, van Hateren KJJ, et al. Metformin associated with lower cancer mortality in type 2 diabetes: ZODIAC- 16 . Diabetes Care. 2010; 33(2): 322-326, doi: 10.2337/dc09-1380, indexed in Pubmed: 19918015.

26. Łukasiewicz D, Jakubowska I, Pędich-Czaban M. Analysis of the occurrence of cancers in patients with diabetes mellitus type 2 . Diabetologia Kliniczna. 2012; 5: 177-184.

27. Sieradzki J, Koblik T, Nazar M. Progress in treatment for type 2 diabetes mellitus based on HbA1c screening in 2002 and 2005. Diabetologia Praktyczna. 2008; 9: 132-139. 